\title{
The Impacts Of The U.S. Financial Crisis On Financial Markets In Asia And Europe
}

Hong Rim, Shippensburg University, PA, USA

Robert Setaputra, Shippensburg University, PA, USA

\begin{abstract}
This study is to examine the impacts of the U.S. financial crisis (2008) on a few financial markets in Asia and Europe in the framework of vector auto-regressive model. This study uses daily returns of the stock market indexes during January 2005-February 2010. Some important findings are: 1) the U.S. market became more integrated with Asian markets during the crisis but less integrated with European markets; 2) the U.S. influence remained strong in both Asia and Europe during the U.S. crisis; 3) the speed of adjustments increased in some markets but decreased in other markets; and 4) there were observed strong spillover effects from the U.S. to other markets during the crisis. The overall results suggest that there still exist much diversification benefits to be exploited in European markets but not much in Asian market.
\end{abstract}

Keywords: Financial Crisis; Integration; Spillover; Vector-Autoregressive Model; and Adjustment Speed.

\section{INTRODUCTION}

C $\mathrm{n}$ recent years, financial markets around the world became more integrated as more countries implemented significant reforms to foster their capital market development by liberalizing financial markets, privatizing various programs, and establishing regulatory and supervisory frameworks. Financial openness, in general, could promote development of domestic financial sector and enhance efficiencies for domestic firms by exposing them to competition from foreign entrants. The benefits of financial integration lie in more efficient way of sharing international risk. Schmukler, Gozzi, and Torre (2007) note that reforms tend to be followed by significant increases in domestic market capitalization, trading, and capital raising, and by an increase in the share of activity in international equity markets (leading to potentially negative spillover impacts on domestic markets). Precious studies show that the inter-market relationships have been greatly affected by various factors such as growing international trade, cross-border investments, and harmonized monetary policies across nations (e.g. Roca et al. 1998, Yang et al. 2003, and Worthington et al. 2003). In integrated financial markets, it has been long debated how one financial crisis originated in one market affects the performance of other markets.

The recent US financial crisis (2008) has spread fast to other countries in integrated global financial markets, which had significant impacts on the operations of many multinational corporations and the lives of numerous individuals around the world. The financial events of this nature could have changed the financial market fundamentals and the relationships between financial markets with different degrees of openness. This study is 1) to examine the impacts of the U.S. financial crisis (2008) on stock markets in Asia and Europe; 2) to examine the speed of adjustments to the shock(s) caused by the U.S. crisis; and 3) to examine the spillover effects thereof. Some of major findings are: 1) Asian markets became more integrated the US market but European markets became less integrated with the US market during the U.S. crisis; 2) the U.S. influence remained strong in both Asian and European markets during the crisis; and 3) the speed of adjustment has not changed greatly in Asian and European markets. The speed of adjustment increased in some markets (i.e., Japan, Singapore, and Germany) but decreased in other markets (i.e., Hong Kong, UK, and France).

This study proceeds as follow. Section II provides literature review. Section III discusses data and empirical results. A Summary and Conclusion follow in Section IV. 


\section{LITERATURE REVIEW}

A group of studies examined the financial market integration around the Asian economic crisis. Montiel (1993) showed high capital mobility between Asian markets (i.e., Korea, Malaysia, the Philippines, Singapore, Thailand), which supports higher integration among these markets. Palac-McMiken (1997) reported that most markets are strongly linked with the Thailand market during 1987-1995. Another group examined the impacts of major economic events on the path of financial integration. Gosh et al. (1999) found three different types of stock markets with distinctive features during the Asian crisis: the first group (e.g., Hong Kong, Korea, and Malaysia) was significantly influenced by the U.S. stock market; the second group (e.g., Indonesia, Philippines, and Singapore) was by the Japanese stock market; and the third group (i.e., Thailand and Taiwan) was not affected by any other markets. Worthington et al. (2003) reported that the relationships between developed and emerging stock markets have become weaker after the Asian crisis. Yang et al. (2003) noted that both long-run cointegration and short-term causal linkages between stock markets became stronger during the Asian crisis; and the US market significantly affected the Asian markets. Fooladi and Rumsey (2006) reported that despite increased integration during January 1988-June 2000, diversification benefits (measured in U.S. dollars) persist, and the increased co-movements between stock markets (in local currencies) had been counterbalanced by higher volatility in the exchange rate changes. Forbes and Rigobon (2002) found strong co-movements between stock markets after the Mexican peso crisis (1994), the Black Monday (1997), and the Asian economic crisis (1997).

The other group of studies examined the impacts of the NAFTA implementation. Kanas (2000) examined interdependencies between stock markets and exchange rates for six industrialized countries (i.e., U.S., UK, Japan, Germany, France, and Canada) and provided strong evidences of volatility spillovers from stock markets to exchange rates but not strong spillover effects from exchange markets to stock markets. This finding is consistent with the notion that international financial markets have become increasingly integrated. Darrat and Zhong (2005) reported that Asian stock markets have long-run relationships before the NAFTA, but not after its implementation.

\section{DATA AND EMPIRICAL RESULTS}

This study uses daily stock returns of 6 ( 3 Asian and 3 European) market indexes during January 2005 February 2010. To better account for the impacts of the U.S. crisis, the period is divided into 2 sub-periods: 2005.1 2007.8 (before the crisis), and 2007.9 2010.2 (during the crisis).

The first step in empirical tests is to examine the stationarity of market indexes (i.e., unit root test) by using the Augmented Dickey-Fuller (Dickey and Fuller (1979), Granger (1988)) model. The results (not reported here) show that each index contains a unit root. Thus, the return series are used in empirical tests below.

The descriptive statistics of daily returns (annualized) before and during the U.S. financial crisis are presented in Table 1. The mean return during the crisis is much lower than that before the crisis. The two means are significantly different at the 5\% level. Before the U.S. crisis, the average U.S. return is $11.6 \%$. In Asia, Hong Kong posted the highest average return of $29.1 \%$, followed by Singapore (27.6\%) and Japan (21.1\%). In Europe, Germany posted the highest return of $31.4 \%$, followed by France $(21.0 \%)$ and UK (14.3\%). The average return of Asian markets is $25.9 \%$, which is higher than $22.2 \%$ for European markets and $11.6 \%$ for the US market. In measuring absolute riskiness, Asian markets have higher standard deviations (SD) of $347.6 \%$ (average) than $307.4 \%$ for European markets. That is, Asian markets had been more volatile than European markets.

During the U.S. crisis, Hong Kong had a small gain of $4 \%$, followed by Singapore (3.8\%) and Japan ($13.8 \%)$. In Europe, UK posted a smaller gain of $1.5 \%$, followed by Germany $(-3.9 \%)$ and France $(-10.2 \%)$. The average SD for Asian markets is $750 \%$, which is higher than $673 \%$ SD for European markets. The Coefficient of Variations (CoV), as the relative risk measurement, increased as much as $702 \%$ (from 13.77 to 110.5) in Asian market and 303\% (from 14.97 to 60.33) in European markets. In contrast, the CoV for the U.S. decreased by 30.9\% (from 21.75 to 15.03 ). 
Table 1.A Descriptive Statistics (annualized) before the US Crisis

\begin{tabular}{|l|c|c|c|c|c|c|c|}
\hline \multirow{4}{*}{$\begin{array}{l}\text { Mean } \\
\text { Maximum }\end{array}$} & US & JAP & HK & SIN01 & UK & GER & FRA \\
\cline { 2 - 8 } & 0.116 & 0.211 & 0.291 & 0.276 & 0.143 & 0.314 & 0.210 \\
\hline $\begin{array}{l}\text { Minimum } \\
\text { Std. Dev. }\end{array}$ & 8.967 & 13.085 & 21.636 & 22.346 & 12.790 & 9.633 & 9.257 \\
\hline
\end{tabular}

Table 1.B Descriptive Statistics (annualized) after the US Crisis

\begin{tabular}{|c|c|c|c|c|c|c|c|}
\hline \multirow{4}{*}{$\begin{array}{c}\text { Mean } \\
\text { Maximum }\end{array}$} & US & JAP & HK & SIN01 & UK & GER & FRA \\
\cline { 2 - 8 } & -0.047 & -0.138 & 0.040 & 0.038 & 0.015 & -0.039 & -0.102 \\
Minimum & 42.267 & 36.352 & 52.367 & 28.548 & 35.911 & 41.617 & 40.793 \\
Std. Dev. & -32.978 & -41.633 & -46.355 & -30.399 & -32.296 & -26.148 & -32.984 \\
\hline
\end{tabular}

The second step is to examine correlation coefficients (CCs). Table 2 provides the CCs before and during the U.S. crisis. The average CC between the US and Asian markets increased from 0.0884 before the crisis (Table 2.A) to 0.2437 during the crisis (Table 2.B). The average CC between the US and European markets decreased from 0.1128 to -0.0566 . During the crisis, the CCs between Asian markets increased but those between European markets greatly decreased. Interestingly, the CCs between the US and UK and France became negative, suggesting the existence of more diversification benefits between these markets. In sum, the decreased CCs during the crisis suggest more benefits of portfolio diversification to be exploited in European markets.

Table 2.A Correlation Coefficients before the US Crisis

\begin{tabular}{|c|c|c|c|c|c|c|c|}
\hline & US & JAP & HK & SIN & UK & GER & FRA \\
\hline US & 1.0000 & & & & & & \\
\hline JAP & 0.0552 & 1.0000 & & & & & \\
\hline HK & 0.0977 & 0.6050 & 1.0000 & & & & \\
\hline SIN & 0.1124 & 0.5858 & 0.7003 & 1.0000 & & & \\
\hline UK & 0.0381 & 0.3810 & 0.3603 & 0.3478 & 1.0000 & & \\
\hline GER & 0.0139 & 0.1140 & 0.0570 & 0.0563 & 0.0879 & 1.0000 & \\
\hline FRA & 0.0608 & 0.4110 & 0.3587 & 0.3548 & 0.8793 & 0.1127 & 1.0000 \\
\hline
\end{tabular}

Table 2.B Correlation Coefficients after the US Crisis

\begin{tabular}{|c|c|c|c|c|c|c|c|}
\hline & US & JAP & HK & SIN & UK & GER & FRA \\
\hline US & 1.0000 & & & & & & \\
\hline JAP & 0.1606 & 1.0000 & & & & & \\
\hline HK & 0.2814 & 0.6934 & 1.0000 & & & & \\
\hline SIN & 0.2891 & 0.6336 & 0.7622 & 1.0000 & & & \\
\hline UK & -0.0886 & 0.0067 & -0.0521 & 0.0014 & 1.0000 & & \\
\hline GER & 0.0202 & 0.0469 & 0.0152 & -0.0012 & 0.0256 & 1.0000 & \\
\hline FRA & -0.1013 & 0.0027 & -0.0615 & -0.0223 & 0.1666 & 0.0626 & 1.0000 \\
\hline
\end{tabular}


The third step is to examine the impacts of the U.S. crisis on other markets, using the GARCH (generalized autoregressive conditional heteroskedasticity) model (Bollerslev1986), in the framework of vector auto-regressive (VAR) model. Since the GARCH model (Engle 1982) considers the variances of the current and previous error terms, it is good for financial time series with time-varying volatility clustering to identify how financial event(s) affects equity returns. To this end, the following GARCH model (Engle 2001) is used:

$r_{i t}=a+\beta_{i u} r_{u t}+\varepsilon_{i t}$

$\sigma^{2}{ }_{\text {it }}=\omega_{\text {io }}+a_{i 1} \sigma_{i t-1}^{2}+a_{i 2} \varepsilon^{2}$ it- 1

where $\mathbf{r}_{\mathbf{i t}}$ is an individual ("ith country") market return at $t ; \mathbf{r}_{\mathbf{u t}}$ is the US-market return; $\boldsymbol{\varepsilon}_{\mathbf{t}}$ is an error term for "unexpected and idiosyncratic shock"; $\boldsymbol{\sigma}_{\mathrm{t}}{ }^{2}$ is conditional variance; $\boldsymbol{\varepsilon}_{\mathrm{t}-1}^{\mathbf{2}}$ refers to the ARCH effect; and $\boldsymbol{\sigma}_{\mathrm{t}-\mathbf{1}}^{\mathbf{2}}$ refers to the GARCH effect.

The mean equation, Model (1), is a function of exogenous variables (i.e., U.S. crisis factor) with an error term: An individual market return is affected by the U.S. financial crisis and an unexpected contemporary shock (i.e., error term, $\left.\varepsilon_{\mathbf{t}}\right)$. The coefficient $\boldsymbol{\beta}_{\boldsymbol{i}, \boldsymbol{U}}$ refers to the U.S. market influence. The conditional variance $\left(\sigma_{t}^{2}\right)$ equation, Model (2), reflects the ARCH effects of innovations (i.e., $\varepsilon^{2}$ ) and the possibility of volatility spillover effect (i.e., GARCH error $\left(\sigma_{t}^{2}\right)$ ). This model suggests that the conditional variance $\left(\sigma_{t}^{2}\right)$ is determined by three factors, the mean $\left(\omega_{0}\right)$, the ARCH term $\left(\varepsilon_{\mathrm{t}-1}^{2}\right)$ (i.e., news-related volatility from the previous period), and the GARCH term $\left(\sigma_{\mathrm{t}-1}^{2}\right)$ (i.e., previous period's forecast variance).

In dealing with time series data, this study uses a GARCH (p, q) (p being the order of GARCH term; $q$ being the order of ARCH term) to examine the effects of ARCH and GARCH errors. In selecting the optimal numbers of lags (p, q), the Ljung-Box statistics are used to minimize the AIC statistics until their values are less than the critical value (e.g., $5 \%$ significant). Empirical results suggest the GARCH $(1,1)$ with the presence of a first order GARCH term and a first order ARCH term.

Table 3 Empirical Results of the GARCH model

\begin{tabular}{|c|c|c|c|c|c|c|}
\hline \multirow{4}{*}{$\begin{array}{c}\text { JAP } \\
\text { (p-value) }\end{array}$} & \multicolumn{2}{|c|}{ US } & \multicolumn{2}{|c|}{$e(t-1)$} & \multicolumn{2}{|c|}{$V(t-1)$} \\
\hline & Before & After & Before & After & Before & After \\
\hline & 0.0708 & 0.0953 & 0.8805 & 0.1078 & 0.1231 & 0.8492 \\
\hline & 0.1234 & 0.0000 & 0.0000 & 0.0035 & 0.0000 & 0.0000 \\
\hline \multirow[t]{2}{*}{ HK } & 0.1236 & 0.0636 & 0.9222 & 0.2373 & 0.1248 & 0.8534 \\
\hline & 0.0083 & 0.0000 & 0.0000 & 0.0000 & 0.0000 & 0.0000 \\
\hline \multirow[t]{2}{*}{ SIN } & 0.0508 & 0.1001 & 0.8937 & 0.2155 & 0.0774 & 0.9147 \\
\hline & 0.1595 & 0.0000 & 0.0000 & 0.0000 & 0.0000 & 0.0000 \\
\hline \multirow[t]{2}{*}{ UK } & 0.1706 & 0.1501 & 0.8065 & -0.0021 & 0.0936 & 0.9005 \\
\hline & 0.0000 & 0.0000 & 0.0000 & 0.9358 & 0.0000 & 0.0000 \\
\hline \multirow[t]{2}{*}{ GER } & 0.0340 & 0.0681 & 0.8884 & 0.0780 & 0.1017 & 0.8901 \\
\hline & 0.4570 & 0.0008 & 0.0000 & 0.0217 & 0.0000 & 0.0000 \\
\hline \multirow[t]{2}{*}{ FRA } & 0.2332 & 0.1028 & 0.8536 & -0.0602 & 0.1063 & 0.8820 \\
\hline & 0.0000 & 0.0000 & 0.0000 & 0.0973 & 0.0000 & 0.0000 \\
\hline
\end{tabular}


Table 3 presents empirical results of a GARCH $(1,1)$ model. Before the crisis, the U.S. market has significant impacts on three (Hong Kong, UK and France) markets. After the crisis, however, the U.S. market has more significant impacts on all 6 markets. The significance of individual indexes suggests that the U.S. market played a significant role in these markets, suggesting that the U.S. market had been a dominant force during the crisis. The significance of ARCH and GARCH terms for all markets supports the argument of strong volatility spillover effects across financial markets mostly from the U.S. market to the other markets. Furthermore, the significance of GARCH terms supports the financial contagion effects during the crisis.

The results from the correlation analyses suggest that the U.S. market became more integrated with Asian markets but less with European markets. The results from the GARCH analyses show that the U.S. influence remained strong and became much stronger in all markets of Asia and Europe during the crisis. And the speed of adjustments increased in three markets (i.e., Japan, Singapore, and Germany) while decreased in other markets (i.e., Hong Kong, UK, France). During the crisis, strong spillover effects were observed from the U.S. to other markets.

\section{SUMMARY AND CONCLUSION}

This study examined the impacts of the US financial crisis on financial markets in Asia and Europe. Some important findings are: 1) the US market became more integrated with Asian markets during the US crisis but less with European markets; 2) the US influence remained strong in both Asia and Europe during the crisis; 3) the speed of adjustments increased in some markets but decreased in other markets; and 4) there were observed strong spillover effects from the U.S. to other markets during the crisis. The overall results suggest that there still exist much diversification benefits to be exploited in, especially, European markets. It is suggested that future studies examine both developed and developing financial markets with other major economic/financial events (e.g., Asian crisis (1997), Mexican crisis (1997), Turkey crisis (2001), Russian crisis (1998)) for longer periods.

\section{AUTHOR INFORMATION}

Hong Rim has been a professor of Finance (Dept. of Finance \& Supply Chain Management) at Shippensburg University (PA, USA) since 1986. He graduated with a Ph.D. in Finance from Pennsylvania State University. His research interest lies in the foreign exchange (FX) markets, including such topics as FX market efficiency, FX rate determination, pricing of exchange-rate risk, and inter-market relationships. His papers have been published in such academic and practice journals as Financial Practice and Education, Journal of Business Finance and Accounting, International Journal of Finance, Journal of Applied Business Research, Journal of Business Research, International Business and Economics Research Journal, Global Business and Finance Review, Modeling and Simulation, and Pacific-Basin Finance Journal. He had been a Fulbright visiting scholar at University Malaysia Sabah (Malaysia) in 2001. He also taught various business courses at Bangkok University (Thailand), Kyungpook National University (S. Korea), and GyeongSang National University (S. Korea). E-mail: hkrim@ship.edu. Corresponding author.

Robert Setaputra is an associate professor of Supply Chain Management at John L Grove College of Business, Shippensburg University (PA, USA). He received his Ph.D. in Operations Management from University of Wisconsin Milwaukee. His current research interest includes e-business, reverse logistics, and supply chain management. He is also interested in interdisciplinary research and has collaborated within the area of finance. His articles have appeared in Journal of Management, International Journal of Physical Distribution and Logistics Management, European Journal of Operational Research, and International Business and Economics Research Journal. E-mail: rsseta@ship.edu

\section{REFERENCES}

1. Bailey, W., and R. M. Stulz. 1990. Benefits of international diversification: the case of Pacific-Basin stock markets. Journal of Portfolio Management 16(1), 57-61.

2. Bollerslev, T. 1986. Generalized autoregressive conditional heteroskedasticity. Journal of Econometrics 31(3), 307-327. 
3. Click, R. W. and M. G. Plummer. 2005. Stock market integration in ASEAN after the Asian financial crisis. Journal of Asian Economics 16(1), 5-28.

4. Daly, K. J. 2003. Southeast Asian Stock Market Linkages. ASEAN Economic Bulletin 20(1), 73-85.

5. Darrat, A. F., and M. Zhong. 2005. Equity market linkage and multinational trade accords: The case of NAFTA. Journal of International Money and Finance 24(5), 793-817.

6. DeFusco, R. A., J. M. Geppert, and G. P. Tsetsekos. 1996. Long-run diversification potential in emerging stock markets. Financial Review 31(2), 343-363.

7. Dickey, D.A. and W. A. Fuller. 1979. Distribution of the estimators for autoregressive time series with a unit root. Journal of American Statistical Association 74 (3), 1057-72.

8. Engle, R. 1982. Autoregressive conditional heteroskedasticity with estimates of the variance of U.K. inflation. Econometrica_50, 987-1008.

9. Fooladi, I.J., and J. Rumsey. 2006. Globalization and portfolio risk over time: The role of exchange rate. Review of Financial Economics 15(3), 223-236.

10. Forbes, K., and R. Rigobon. 2002. No contagion, only Interdependence: Measuring Stock Market CoMovement. Journal of Finance 57(5), pp. 2223-2261.

11. Ghosh, A., R. Saidi, and K. Johnson. 1999. Who moves the Asia-Pacific stock markets-US or Japan? Empirical evidence based on the theory of cointegration. Financial Review 34(1), 159-170.

12. Granger, Clive W.J. 1988. Some recent developments in a concept of causality. Journal of Econometrica 39, 199-211.

13. Johansen, S. 1995. Likelihood-based Inference in Cointegrated Vector Autoregressive Models. Oxford University Press, Oxford.

14. Kanas, Angelos. 2000. Volatility Spillovers between Stock Returns and Exchange Rate Changes: International Evidence. Journal of Business Finance \& Accounting 27 (3- 4), 447-467.

15. Kose, M. Avan, E. S. Prassad, and M.E. Terrones. 2008. How does Financial Globalization Affect Risk Sharing? Patterns and Channels. IMF Working paper No. 07/238.

16. Montiel, P.J. 1993. Capital mobility in developing countries: Some measurement issues and empirical estimates. World Bank Debt and International Finance Policy Research Working Paper No. 1103.

17. Palac-McMiken, E. D. 1997. An examination of ASEAN stock market: A cointegration approach. ASEAN Economic Bulletin 13(2), 299-311.

18. Roca, E. D., E. A. Selvanathan, and W. F. Shepherd. 1998. Are the ASEAN equity markets interdependent? ASEAN Economic Bulletin 15(1), 109-120.

19. Schmukler, Sergio L., Juan Carlos Gozzi, and Augusto De La Torre. 2007. Stock Market Development Under Globalization: Whither the Gains from Reforms? World Bank Policy Research Working Paper No. 4184;

20. Worthington, A.C., M. Katsuura, and H. Higgs. 2003. Price linkages in Asian equity markets: Evidence bordering the Asian economics, currency, and financial crises. Asia-Pacific Financial Markets 10(1), 2944.

21. Yang, J., J. W. Kolari, and I. Min. 2003. Stock market integration and financial crises: The case of Asia. Applied Financial Economics 13(3), 477-486. 